技術論文

\title{
새로운 $\mathrm{Z}^{-}$피닝 기술로 제작된 복합적층판의 내충격 특성
}

최익현*, 안석민*, 염찬홍*, 황인희*, 이대성*

\section{Impact Resistance of Composite Laminates Manufactured by New z-Pinning Technique}

Ik-Hyeon Choi*, Seok-Min Ahn*, Chan-Hong Yeom*, In-Hee Hwang* and Dae-Sung Lee*

\begin{abstract}
In this paper, conventional z-pinning technology which can be used to reinforce inter-laminar property of laminated composites is introduced and new z-pinning technique recently proposed by author is also introduced. On some trial specimens manufactured by the new z-pinning technique, the low-velocity impact test was performed and impact damage area was measured. Similar impact test was performed on normal composite laminate specimens and those test results were compared to each other. Consequently, it can be seen that the new z-pinning technique is more useful in applying to mass production of z-pinned composite laminate structures than the conventional techniques and some clear improvement on impact resistance of z-pinned composite laminates manufactured by the new z-pinning technique is observed.
\end{abstract}

\section{초록}

본 논문에서는 복합적층판의 취약한 층간 특성을 보강할 수 있는 $\mathrm{z}$-피닝 기술에 대하여 기존에 알려진 방법들을 소개하고, 최근 저자에 의하여 제안된 새로운 방법을 소개하였다. 새로운 방법을 적용하여 시제작된 $\mathrm{z}$-피닝 시편들에 대하여 충격시험을 수행하고, 충격손상 영역을 측정하였다. $\mathrm{z}$-피닝 기술이 적용되지 않은 일반 복합재 시편에 대해서도 동일한 시 험을 수행하고, 두 결과를 서로 비교하였다. 결과적으로 새로운 $\mathrm{z}$-피닝 기술은 기존의 기 술에 비하여 양산에 적용하기가 매우 유리한 장점이 있으며, 새로운 $z$-피닝 기술이 적용된 복합적층판 시편들의 내충격 특성이 확실히 향상되고 있음을 알 수 있었다.

Key Words : Composite(복합재료), Laminate(적층판), z-Pinning(z-피닝), Inter-laminar(층간), Impact Damage(충격손상)

I. 서 론

탄소섬유강화 고분자 복합재료는 최근 항공기 구조재료로 매우 활발하게 적용되고 있다. 민간 여객기인 $\mathrm{B} 787$ 에는 복합재료의 비중이 전체구조

† 2009년 5월 12일 접수 2009년 6월 25일 심사완료

* 정회원, 한국항공우주연구원

교신저자, E-mail : ihchoi@kari.re.kr

대전시 유성구 과학로 115
중량대비 $50 \%$ 에 달하고 있다.

항공기 구조는 경량화를 위하여 주로 셀이나 판 형태의 구조물로 설계되고 있으며, 중요한 하 중 전달이 판의 면내(in-plane) 응력의 형태로 전 달된다. 항공기 구조로 복합재료를 사용하는 경 우에도, 해당 구조물이 받는 여러 성분의 면내 응력의 전달에 가장 효율적인 적층순서를 분석하 여, 주로 일방향 프리프레그를 다양한 각도로 적 층한 후, 오토클레이브로 성형하는 방법으로 복 합적층 구조물을 제작하고 있다. 복합적층 구조 
물은 두께 방향의 각 층별로 적층각이 변함에 따 라 층과 층 사이에서 층간 응력이 발생할 수 있 다. 특히 면내 방향이 아닌 면외 방향으로부터 하중을 받는 경우에, 즉 외부 물체로부터 충격 하중을 받는 경우에, 큰 층간 응력이 발생하게 된다. 그러나 복합적층판의 두께 방향으로는 아 무런 보강섬유가 존재하지 않고, 단지 기지 (matrix) 재료에 의하여 층과 층이 접착되어 있 기 때문에 쉽게 층간분리(delamination)가 발생 할 수 있다. 이 층간분리는 복합적층 구조물의 압축강도를 저하시켜 구조물의 갑작스런 파단의 원인이 될 수도 있다.

항공기의 복합적층 구조물의 두께 방향에서의 층간 물성의 취약함을 보강하고자 하는 연구는 오래 전부터 많이 수행되어 왔다. 그러나 3차원 적으로 직물을 짜거나, 스티칭(stitching) 등의 기 술은 수지가 함침되기 전의 섬유 프리폼에 적용 하기 적당하다. 이 기술들을 수지가 함침되어 이 미 반경화된 프리프레그에 적용하면, 프리프레그 내부의 많은 보강섬유가 손상되기 때문에, 면내 방향의 물성의 손상이 크다. 따라서 면내 방향의 물성이 매우 중요한 항공기 복합재 구조물에는 스티칭 등의 기술을 적용하기 곤란하다.

프리프레그를 적층하여 성형하는 복합적층 구 조물에 적용하여 취약한 층간 물성을 보강할 수 있는 유일한 방법은 z-피닝(z-pinning)이다. z-피 닝 기술은 아직 많이 알려져 있지 않은 편이지 만, 최근 이에 대한 연구동향을 조사한 논문도 발표되어 있다[1, 2]. 본 논문에서는 먼저 $\mathrm{z}$-피닝 에 대하여 기존에 알려진 기술들을 소개하고, 최 근 저자에 의하여 고안된 새로운 $\mathrm{z}$-피닝 개념에 대해서도 소개한다.

저자는 새로운 $\mathrm{z}$-피닝 개념을 적용하여 $\mathrm{z}$-피닝 시제품을 제작하는데 성공하였으며, 새로운 $\mathrm{z}$-피 닝 기술을 적용하여 시제작된 $\mathrm{z}$-피닝 복합적층판 시편들에 대하여 저속충격시험을 수행하고, 충격 손상영역을 측정하였다. 또한 $\mathrm{z}$-피닝이 적용되지 않은 일반 복합재 시편에 대해서도 동일한 저속 충격시험을 수행하고, 충격손상영역을 측정하였 으며, 두 결과를 서로 비교하였다.

\section{II. 기존의 $z$-피닝 기술}

\section{1 기존의 $z$-피닝 기술 소개}

$\mathrm{z}$-피닝 복합적층 구조물에 있어서, $\mathrm{z}$-핀은 Fig. 1 에서와 같이 마찰과 접착에 의하여 적층구조물 의 두께 방향의 각 층들을 묶는 작은 못의 역할 을 한다. 일반적으로 적층판을 해석하기 위한 좌

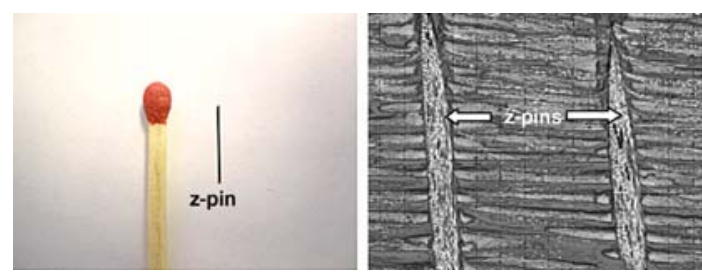

Fig. 1. Photograph of typical z-pin and $z$-pins inserted into prepreg composite laminate.

표계를 설정하는 경우에 두께 방향을 $\mathrm{z}$-방향으로 설정하기 때문에 두께 방향으로 핀이 박힌다는 의미에서 'z-핀'이라는 용어가 사용되고 있다.

z-피닝에 대한 연구는 1980년대에 러시아에서 처음 시작되었으며, 미국에서는 Foster-Miller (사)에 의해 유사한 개념이 처음으로 특허 출원 되었다[3]. 특허 출원된 초기의 $\mathrm{z}$-피닝 개념은 Fig. 2에서 보는 바와 같다. Fig. 2의 첫 번째 그 림과 같이, 압축붕괴가 가능한, 핀이 박힌 '프리 폼(pre-form)'을 적층된 프리프레그의 위에 두고, 프리폼의 상부에는 철판을 두고, 진공 팩킹 (packing)을 한 후, 오토클레이브로 성형한다. Fig. 2의 두 번째 그림과 같이, 성형압력 및 열에 의하여 프리폼이 붕괴되면서 $\mathrm{z}$-핀들이 적층된 프 리프레그 속으로 삽입된다. 오토클레이브에서 성 형이 완료된 후, 성형된 적층구조물을 오토클레 이브에서 꺼내어 Fig. 2의 세 번째 그림과 같이, 적층 구조물 위에 남아있는 압축된 프리폼의 잔 재물을 제거한다. 그리고 Fig. 2의 네 번째 그림 과 같이, 적층구조물의 상부에 돌출되어 남아있 는 $\mathrm{z}$-핀들을 적당한 공구로 잘라 제거한다. Fig. 2 의 마지막 그림은 이 개념이 적층판 자체의 층 간 보강뿐만 아니라 두 적층구조 부재간의 연결 에도 활용할 수 있음을 보여주는 그림이다. 즉 리벳 등의 패스너를 사용하지 않고 $\mathrm{z}$-피닝으로 두 부재를 연결할 수 있음을 보여준다.

하지만 이 개념을 실제 적용하기에는 사전에 정확한 분석이 필요해 보인다. 즉, 성형압력과 열 에 의한 프리폼의 붕괴량을 미리 정확히 예측하 고 프리폼의 두께를 결정하여야 한다. 즉, 프리폼 의 붕괴로 인하여 삽입되는 핀의 깊이가 성형후 의 적층판의 두께와 정확히 일치하여야만, 프리 프레그에도 프리폼을 거쳐 성형압력이 가해져 여 분의 레진을 제거할 수 있고 우수한 성능의 복합 적층 구조물이 성형되기 때문이다. 이러한 개념 상의 어려움 때문인지는 몰라도 아직 이 개념이 실제에 적용되었다는 보고는 없다. 


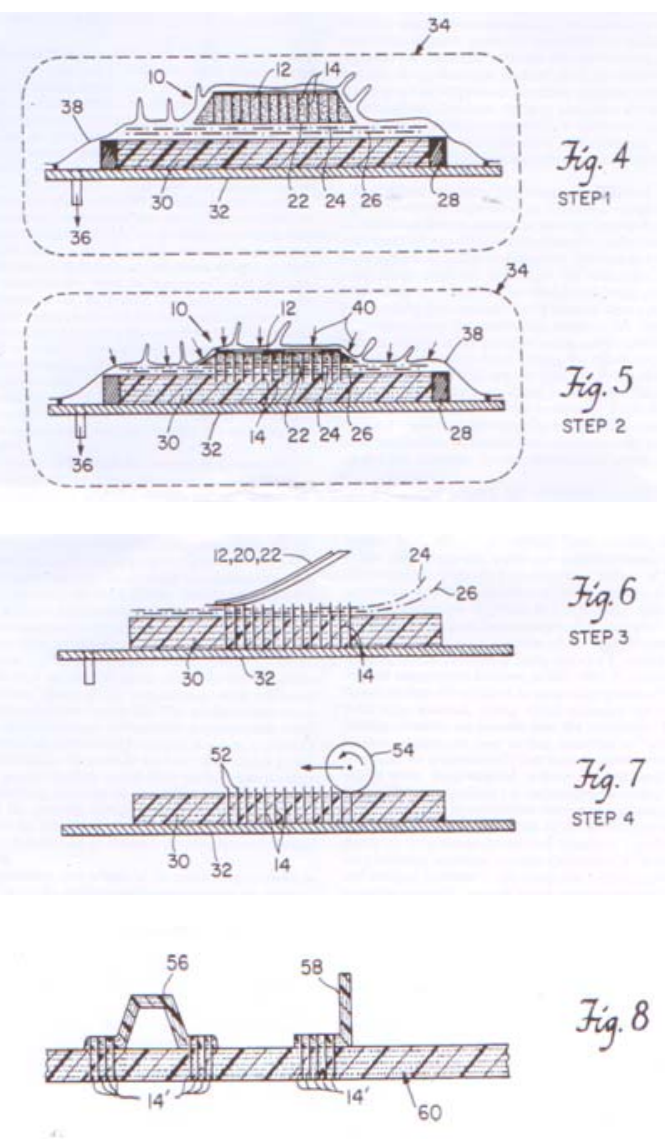

Fig. 2. Initial concept on z-pinning process

Foster-Miller(사)는 이후 프리프레그 적층단계 에서 핀을 미리 삽입하는 $\mathrm{z}$-피닝 개념에 대하여 특허를 출원하였다[4]. 일반적으로 프리프레그는 상온에서 수지의 점성이 매우 강하므로 이 상태 에서 프리프레그의 보강섬유에 손상을 주지 않고 핀을 삽입하기 위해서는 특별한 방법이 필요하 다. 그들은 이를 위하여 고주파로 진동하는 초음 파 혼을 사용하였다. Fig. 3은 이 특허 개념을 보 여주는 그림이다. 초음파 혼의 고주파 진동은 프 리폼 안의 $\mathrm{z}$-핀으로 전달되며, 핀에 전달된 고주 파 진동은 핀의 끝에 접촉되는 프리프레그를 국 소적으로 가열시켜 수지의 점성을 약하게 함으로 써 핀이 삽입되는 것을 쉽게 한다. 초음파 공구 를 프리폼 위에서 점차적으로 누르면서 핀이 프 리프레그를 관통하여 삽입될 때까지 핀을 박는 개념이다.

Fig. 3의 첫 번째 그림은 프리프레그가 적층된 상부 면에 압축붕괴가 가능한, 핀이 박힌 프리폼 을 올려놓는 과정을 보여준다. 여기서 사용되는 프리폼은 이전의 Fig. 2의 개념에서 진보하여,
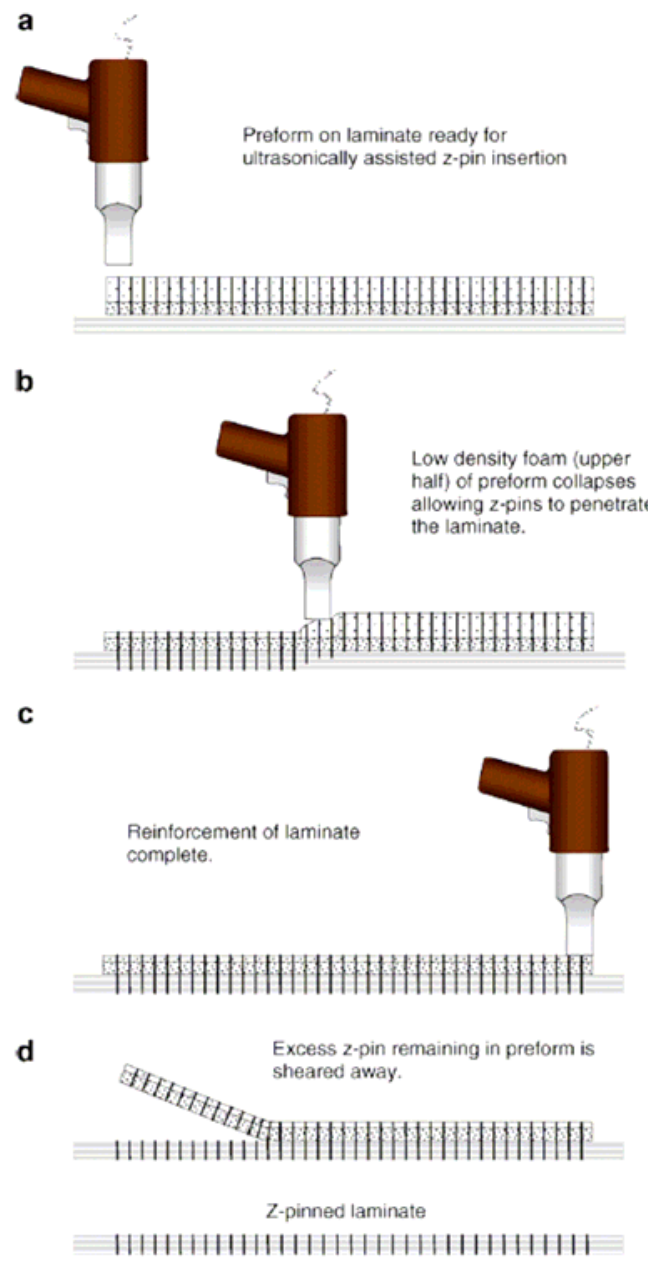

Fig. 3. z-Pinning process using ultrasonic tool
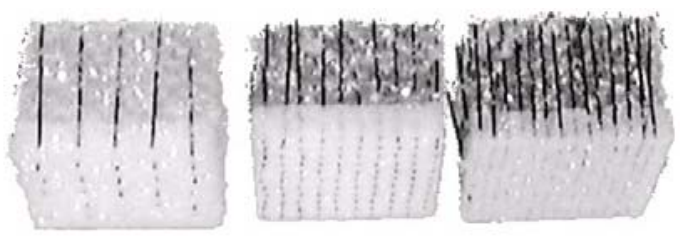

Fig. 4. Typical preform containing z-pins

Fig. 4에서 보는 바와 같이 두 가지 밀도의 폼 재질이 복합적으로 제작되는데, 프리프레그와 접 촉되는 아래쪽은 밀도가 높아 삽입과정에서 옆으 로 쓰러지지 않도록 하는 지지 기능을 가지며 잘 붕괴되지 않는 특성을 갖는다. 프리폼의 위쪽 부 분은 밀도가 낮아 하중을 부가하면 쉽게 붕괴되 는 특성을 갖는다. 프리폼의 이러한 특성은 Fig. 3 의 두 번째 그림에서 확인할 수 있는데, 프리폼 


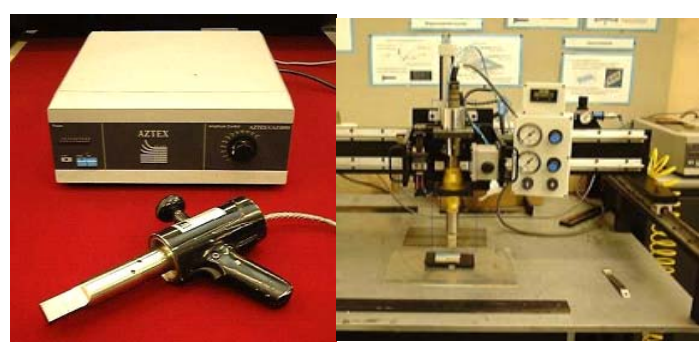

Fig. 5. Ultrasonic horn and gantry system to insert $z$-pin

의 아래 부분은 핀 삽입과정 후에도 두께가 변하 지 않으며, 프리폼의 위 부분만 두께가 압축되는 것을 볼 수 있다. 핀의 삽입이 완료되면 Fig. 3의 네 번째 그림과 같이 프리폼의 잔류물을 제거한 다. 이후 핀 삽입이 완료된 프리프레그 적층구조 물을 오토클레이브를 사용하는 등의 통상적인 복 합재 성형방법으로 성형함으로써, $\mathrm{z}$-핀이 박힌 적층구조물의 제작을 완료하는 것이다.

Fig. 5는 Foster-Miller(사)에 의하여 핀의 삽입 과정에서 실제로 사용되고 있는 초음파 장치를 보여주고 있는데, 첫 번째 그림은 수동식이며, 두 번째 그림은 자동화된 시스템이다. 자동화된 장 치를 사용하면, 한 번에 $1 \mathrm{in}^{2}$ 의 면적에 핀 삽입 을 수행하는데 약 3 4초 정도의 시간이 소요되 며, 한 위치에서 시작하여 작업후 다음 위치로의 이동에는 약 10 초가 소요된다고 한다[5].

Foster-Miller(사)는 이 방법을 적용하여 z-피닝 기술의 실용화에 성공하였다. F/A- $18 \mathrm{E} / \mathrm{F}$ 슈퍼호 넷의 엔진베이 도어와 에어인렛 덕트 연결에, 이 $\mathrm{z}$-피닝 기술을 사용하여 기존에 사용된 티타늄 패스너를 대체한 것이다. 그들은 이 기술을 적용 함으로써 한 대당 83,000 달러의 비용절감과 $17 \mathrm{~kg}$ 의 경량화를 가져왔다고 한다[5]. Partridge 등[5] 은 항공기 구조에 자동화된 $\mathrm{z}$-핀의 삽입은 드릴 링작업 및 금속 패스너를 사용하는 것에 비하여 $70 \%$ 의 제작비를 감소시킬 수 있다고 평가하였 고, $\mathrm{z}$-핀을 삽입하는 시간이 금속 패스너를 설치 하는 시간보다 더 적게 소요된다고 하였다.

이상에서 살펴본 바와 같이 $\mathrm{z}$-피닝 기술은 3 차 원 직조나 스티칭 등의 층간강화 방법에 비하여 뛰어난 장점을 가지고 있다. 먼저 $\mathrm{z}$-피닝은 적층 된 프리프레그의 한 쪽에서만 작업을 수행하여도 된다는 편리성이 있다. 위빙(weaving)이나 스티 칭 등의 다른 $3 \mathrm{D}$ 보강방법들은 성형될 적층판 구조의 양쪽에서 작업이 이루어져야 하기 때문에 매우 복잡하고 생산성이 떨어진다. 또 $\mathrm{z}$-피닝 공 정은 기존의 프리프레그 적층 오토클레이브 성형
공정과 대부분 동일하며, 단지 핀을 삽입하는 공 정만 추가될 뿐이다. 따라서 기존의 오토클레이 브 작업공정을 그대로 사용할 수 있어 현재의 생 산 현장에 도입하여 적용하기가 매우 유리하다.

\section{$2.2 \mathrm{z}$-피닝의 장점}

z-피닝 기술이 실용화된 후 일부 대학 및 연구 소에서 $\mathrm{z}$-피닝 복합적층판의 성능에 대하여 꾸준 히 연구가 진행되어 왔다 $[1,2] . \mathrm{z}$-피닝의 중요한 장점은 충격저항, 손상허용 및 접합강도를 향상 시키는 것이다. $\mathrm{z}$-피닝은 짧은 층간분리 균열의 시작과 성장을 억제하는 데에는 효과적이지 않지 만, $2 \sim 5 \mathrm{~mm}$ 보다 긴 층간분리 균열의 전파를 억 제하는 데에는 매우 효과적이다. 많은 연구에서 $\mathrm{z}$-피닝이 모드 I, II 및 혼합모드에서 층간강성을 강화시킨다고 보여줬다. $\mathrm{z}$-피닝은 층간분리 인성 을 증가시킬 뿐만 아니라, 잘 깨지는 수지재료를 사용한 복합적층판에서 불안정한 균열전파를 안 정적인 균열전파로 변환시키는 장점을 갖는 것으 로 알려져 있다[1].

$\mathrm{z}$-피닝은 특히 충격손상에 대해서 큰 저항성을 보인다. 실험연구에 따르면 $\mathrm{z}$-피닝은 낮은 에너 지 물체에 의한 충격시 층간분리 손상의 크기를 낮춘다. Zhang 등은 $\mathrm{z}$-피닝이 충격손상영역을 에 너지 레벨과 적층판 두께에 따라 $19 \sim 64 \%$ 감소 시킴을 발견했고, Childress과 Freitas은 우박에 의하여 야기되는 손상이 $30 \sim 50 \%$ 감소됨을 알았 다[1]. z-피닝에 의하여 향상된 충격손상에 대한 저항성은 충격후 잔류강도의 높은 값으로 연결된 다.

예로서 Fig. 6은 z-피닝을 한 경우와 안한 경 우에 대한 충격후 압축강도를 비교한 것이다. z피닝 시편의 압축강도가 큰 이유는 충격손상이 작게 발생하고, $\mathrm{z}$-핀의 층간 연결 효과로 인하여 층간분리 영역의 좌굴 저항성이 더 크기 때문이

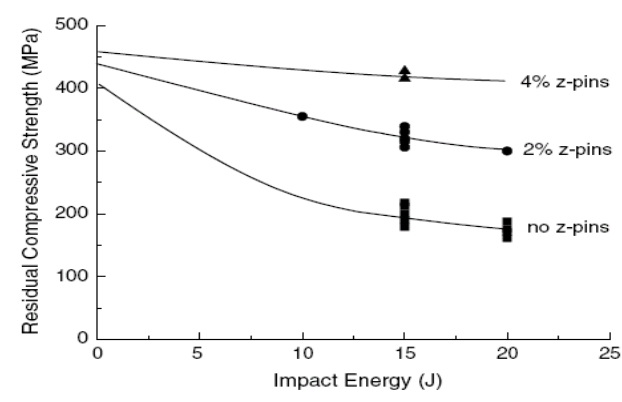

Fig. 6. Effect of $z$-pinning on the residual compressive strength after impact [1] 
다. 체적비 기준으로 $4 \%$ 의 핀 함유율에서 $15 \mathrm{~J}$ 충 격에너지의 충격후 잔류압축강도가 약 2 배 정도 로 향상되었음을 볼 수 있다[1].

항공기에서 복합재 구조 조인트는 고강도와 내피로 특성의 향상을 위하여 리벳이나 스크류 같은 금속 패스너로 보강되곤 하는데, 고정밀도 를 갖는 패스너 홀을 가공하는 데에는 적지 않은 비용이 소요된다. 더구나 패스너 홀들은 부정확 하게 설계되었거나 가공되었을 경우, 피로 손상 또는 베어링 파손의 가능성이 있다. 또한 패스너 홀들은 정확하게 밀폐되지 않을 경우, 습기, 항공 유 및 기타 유체의 인입처가 될 수도 있다.

앞의 Fig. 2의 다섯 번째 그림에서 살펴본 바 와 같이 $\mathrm{Z}$-피닝을 사용하여 두 구조부재를 연결 할 수 있다. $\mathrm{Z}$-피닝 조인트의 장점은 홀의 가공 과 금속 패스너가 필요 없고, 밀폐를 위한 실런 트가 파손되어도 습기 인입에 대한 저항성이 우 수하며, 하중이 조인트 부위에 고르게 분포한다 는 것이다. 이러한 $\mathrm{z}$-피닝의 장점으로 인하여 $\mathrm{z}$ 피닝 기술이 슈퍼호넷의 조인트 부위에 기존의 패스너 대체용으로 가장 먼저 실용화된 것이라 할 수 있다.

한 예로서 Fig. 7은 인장하중을 받는 랩 조인 트의 극한강도와 피로수명에 대한 $\mathrm{z}$-핀의 효과를 보여준다. 극한강도는 $2 \%$ 핀 함유율에서 $41 \%$ 향 상되었고, 피로 수명은 $4 \%$ 핀 함유율에서 약 $40 \%$ 정도의 향상이 있었다고 한다[1].
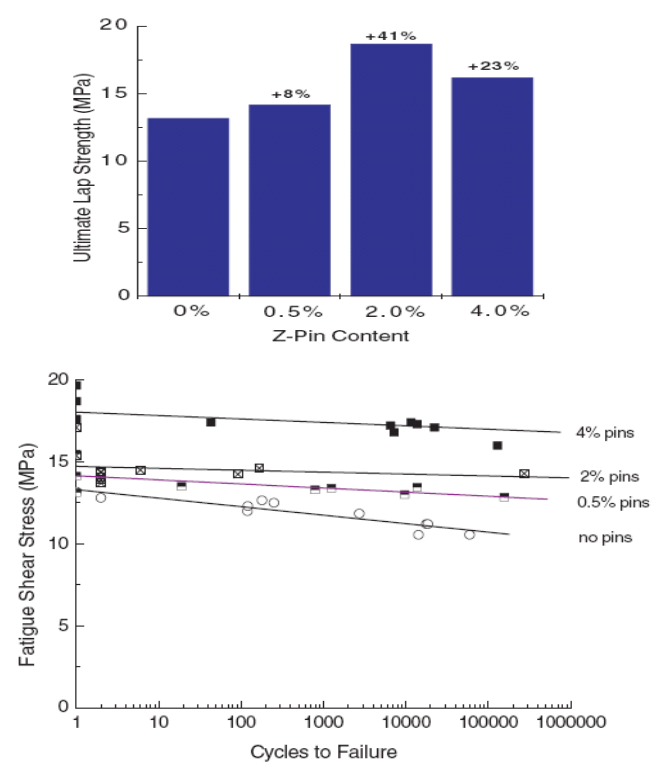

Fig. 7. Effect of $z$-pinning on the ultimate strength (upper) and fatigue life (lower) of composite lap joint [1]

\section{III. 새로운 $z$-피닝 개념}

\section{1 새로운 $z-$ 피닝 개념 소개}

저자는 최근에 $\mathrm{z}$-피닝에 대하여 새로운 개념 [6]을 적용하여, $\mathrm{z}$-핀이 박힌 복합적층판 시제품 을 제작하는데 성공하였다. 즉, 기존의 개념들과 는 달리, $\mathrm{z}$-핀을 포함하고 있는 일회용 프리폼을 사용하지 않고, 반복사용이 가능한 치구개념을 도입하여 오토클레이브 성형공정을 통하여 복합 적층판에 $\mathrm{Z}$-핀이 삽입되도록 하였다. Fig. 8과 9 는 이 개념을 보여주는 그림이다. Fig. 8은 z-핀 들이 프리프레그 적층 구조물에 삽입되기 전의 모습이며, Fig. 9는 삽입된 후의 모습이다.

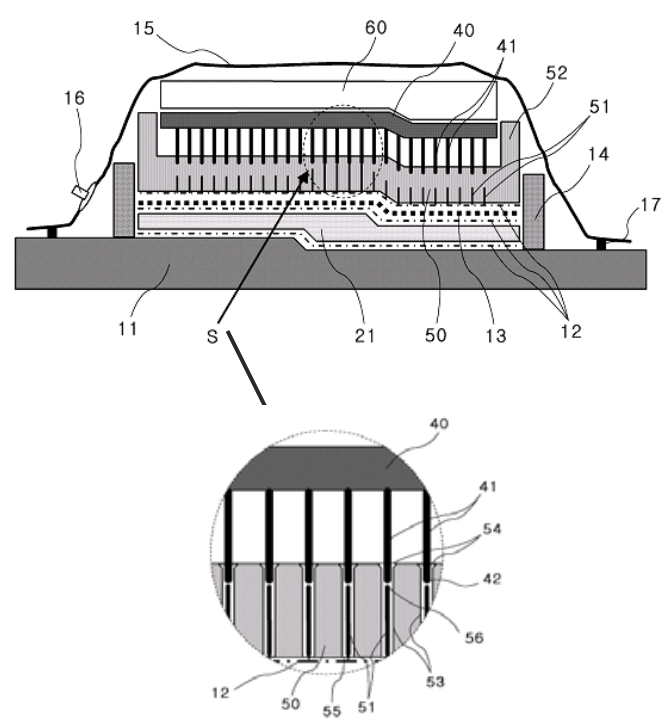

Fig. 8. New z-pinning concept using repeatedly usable fixture system (before inserting of $z$-pins)

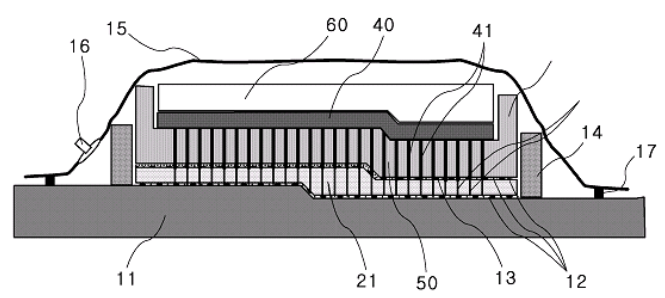

Fig. 9. New z-pinning concept using repeatedly usable fixture system (after inserting of $z$-pins) 
이 개념에서 치구는 상부 치구와 하부 치구로 구성된다. 상부치구에는 하부치구의 두께와 동일 한 크기의 길이를 갖는 가이드 핀들이 설치되어 있다. 하부치구에는 가이드 핀들에 대응하는 구 멍들이 뚫려 있으며, 이 구멍에는 적층 구조물 내부로 삽입될 $\mathrm{z}$-핀들이 들어있다. $\mathrm{z}$-핀의 길이는 성형후의 복합적층 구조물의 두께와 동일하다. 이 상하부 치구를 Fig. 8에서 보는 바와 같이 적 층된 프리프레그 위에 놓고 진공 패킹을 한 후 오토클레이브 내부에서 성형한다. 성형압력에 의 하여 상부치구가 하부치구 쪽으로 눌려지면서 Fig. 9에서 보는 바와 같이 상부치구의 가이드 핀들이 하부 치구의 구멍 속의 $\mathrm{z}$-핀들을 밀어 적 층된 프리프레그 안으로 삽입시키게 된다.

이 새로운 개념은 오토클레이브의 성형 압력 을 이용한다는 측면에서 앞의 Fig. 2의 개념과 유사한 측면이 있지만, 앞의 $\mathrm{z}$-피닝 개념들보다 뛰어난 몇 가지 장점을 가지고 있다. 첫째, 프리 폼을 사용하지 않기 때문에, 기존의 개념에서처 럼 프리폼의 압축되는 양을 정확히 분석하여 복 합적층 구조물의 두께에 따라 프리폼의 두께를 결정하고 제작하느라 고민할 필요가 없다. 즉, 본 논문의 개념에서는, 삽입되는 $\mathrm{z}$-핀의 길이를 성 형후의 적층판의 두께와 일치시키기만 하면, 성 형시 $\mathrm{z}$-핀의 삽입이 완료된 후 성형압력이 프리 프레그로 전달되어 프리프레그 내부의 여분의 수 지가 충분히 제거될 수 있다. 특히 적층 구조물 의 두께가 변하는 경우에도 삽입되는 위치에서의 복합적층 구조물의 두께와 길이가 같은 $\mathrm{z}$-핀을 하부 치구의 구멍 속에 삽입하여 두는 것으로 문 제가 해결된다. 둘째, 일회용 프리폼을 사용하지 않기 때문에, 성형후 잔재물을 제거할 필요가 없 을 뿐만 아니라 일회용에 의한 재료의 낭비가 전혀 없다. 셋째, 기존의 오토클레이브 공정에 변 화가 거의 없다. 즉, 기존의 오토클레이브 공정이 정확히 그대로 유지되면서 단지 상하부 치구 세 트를 마치 컬 플레이트(curl plate)처럼 적층된 프리프레그의 위에 두고 성형하기만 하면 된다. 넷째, 일단 치구 세트가 제작되면 넓은 면적이라 도 오토클레이브 성형 작업과 동시에 단번에 $\mathrm{z}$ 핀 삽입작업이 가능하다.

\section{2 새로운 $z$-피닝 개념의 시제품}

앞 장에서 살펴본 바와 같이 기존의 $\mathrm{z}$-피닝 기 술에 비하여 많은 장점을 갖는 $\mathrm{z}$-피닝 신기술을 적용하여 치구 세트 시제품을 제작하고, 시제작 된 치구 세트를 사용하여 $\mathrm{z}$-피닝 복합적층판의 시제품 제작을 시도하였다.
Fig. 10은 시제작된 상하부 치구 세트를 보여 주는 사진들이다. 좌측은 상부치구를 보여주며, 많은 가이드 핀들이 설치되어 있음을 볼 수 있 다. 우측은 하부치구를 보여주며, 상부의 가이드 핀들에 대응하는 많은 구멍들을 볼 수 있다. 치 구 가장자리에는 상부 치구와 하부치구가 정확히 조립되도록 가이드 역할을 하는 볼트류들이 설치 되어 있다.

Fig. 11은 새로운 z-피닝 개념을 적용하여 제 작된, 전형적인 $\mathrm{z}$-피닝 복합적층판 시제품을 보 여주고 있다. 시제작에 사용된 복합소재는 $\mathrm{T} 300 / 934$ 카본/에폭시 소재이며, 적층순서는 $[0 / 45 / 0 /-45 / 0 /-45 / 0 / 45 / 90]_{S}$ 이다. 시편의 크기 는 $175 \times 175 \mathrm{~mm}$ 이고, 두께는 $2.25 \mathrm{~mm}$ 이다. 소 재의 물성치는 Table 1 과 같다. 중앙 부위에는 충격시험으로 인하여 국부적으로 손상이 발생한 것을 보여준다. 충격 손상영역의 바깥쪽으로 손 상영역보다 더 넓은 사각형의 면적 $(90 \times 90 \mathrm{~mm})$ 에 z-핀이 박혀있음이 사진에서 식별된다.

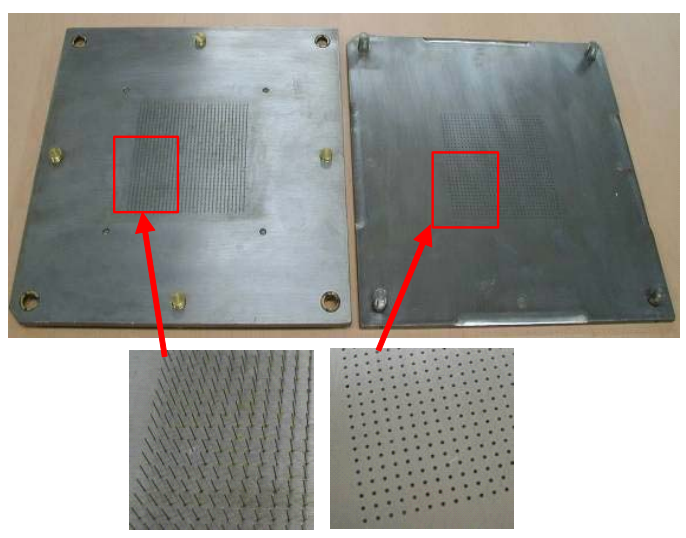

Fig. 10. Trial fixture set for new z-pinning concept

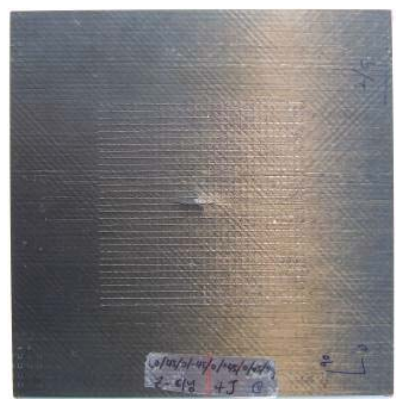

Fig. 11. Typical z-pinned composite laminate manufactured by new z-pinning concept 

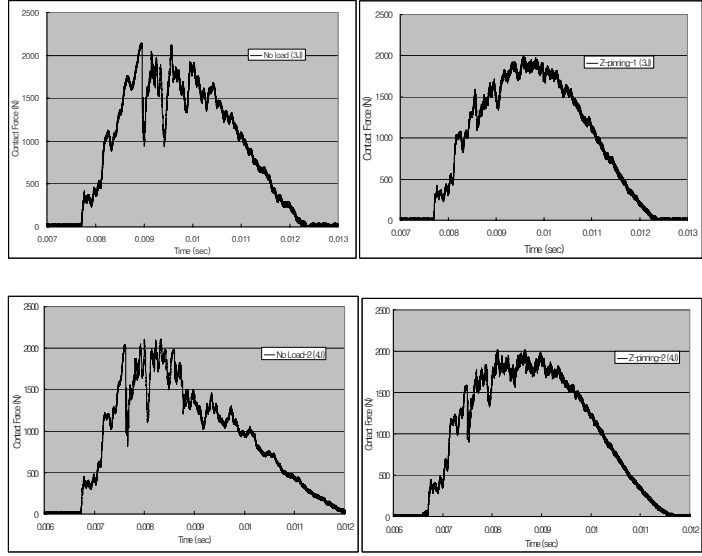

Fig. 12. Contact force histories of normal (left) specimens and $z$-pinned (right) specimens by impact test under $3 \mathrm{~J}$ (upper) and $4 \mathrm{~J}$ (lower) impact energy level

Fig. 12는 일반 시편 (왼쪽 그림)과 시제작된 $\mathrm{z}$-피닝 시편 (오른쪽 그림)에 대하여, 충격시험시 계측된 접촉하중이력 곡선들을 보여준다. 이 때 충격에너지는 각각 $3 \mathrm{~J}$ (위쪽 그림)과 $4 \mathrm{~J}$ (아래쪽 그림)인 경우이다. Fig. 12를 살펴보면 일반 시편 의 접촉하중이력은 $\mathrm{z}$-피닝 시편의 접촉하중이력 에 비하여 하중이력의 변동이 매우 크게 나타나 고 있음을 볼 수 있다. 일반적으로 접촉하중이력 의 변동은 접촉되는 두 물체의 어느 쪽에선가 강 성의 변화가 갑자기 발생하는 경우에 크게 발생 하게 된다. 즉, 일반 시편에서 접촉하중이력의 변 동성이 크게 나타난다는 것은 일반 시편에서 충 격으로 인한 손상이 더 많이 발생하고 있음을 의 미하는 것이라 할 수 있다.

Fig. 13은 위 시편들의 충격손상을 C-스캐닝 (C-scanning) 방법으로 측정한 것이다. 즉, 일반 시편 (왼쪽)과 시제작된 $\mathrm{z}$-피닝 시편 (오른쪽)에 대하여, 측정된 충격손상영역을 보여준다. 이 때 충격에너지는 각각 $3 \mathrm{~J}$ (위쪽)과 $4 \mathrm{~J}$ (아래쪽)인 경 우이다. Fig. 13을 살펴보면, Fig. 12의 접촉하중 이력 곡선에 대한 분석 과정에서 이미 예측된 바 와 같이, $\mathrm{z}$-피닝 시편의 충격 손상영역이 일반 시편의 충격 손상영역에 비하여 확실히 작게 나 타나고 있음을 확인할 수 있다.

Table 1. Material Properties of Carbon/Epoxy prepreg

$E_{1}=132 \mathrm{GPa}, \quad E_{2}=E_{3}=7.995 \mathrm{GPa}$
$G_{12}=3,74 \mathrm{GPa}, \quad v_{12}=0.30$
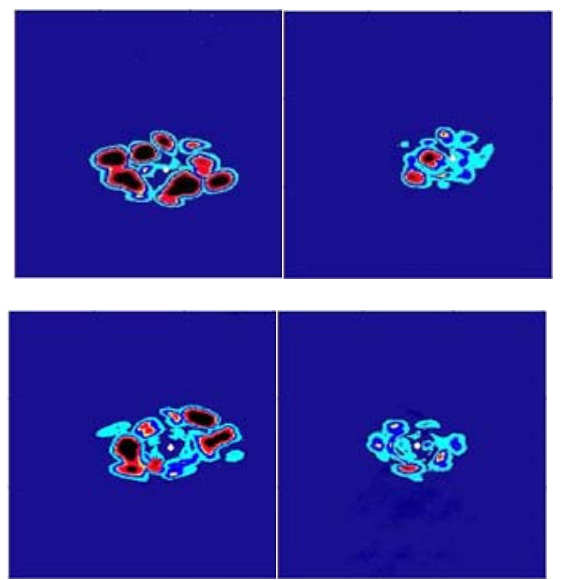

Fig. 13. C-scanned impact damage area of normal (left) specimens and z-pinned (right) specimens under $3 \mathrm{~J}$ (upper) and $4 \mathrm{~J}$ (lower) impact energy level

복합재의 손상을 검사하기 위하여 사용하는 비파괴검사 방법의 하나인 C-스캐닝은 프로브라 는 $5 \sim 10 \mathrm{MHz}$ 의 고주파 발진기를 사용하여 적층 판의 두께방향으로 초음파를 주사하고, 이에 대 한 반사파를 측정하여 판의 두께방향으로 분리된 층이 있는지를 검사하는 것으로, $\mathrm{C}$-스캐닝으로 측정되는 손상영역은 일반적으로 층간분리 영역 으로 판단한다.

본 연구에서는 $\mathrm{z}$-피닝 시편의 성능을 확인하기 위하여 먼저 일반시편과의 성능 비교를 수행하였 다. 향후에는 일반시편과의 비교 뿐만 아니라 타 $\mathrm{z}$-피닝 기술로 제작된 시편과도 성능 비교를 수 행할 필요가 있다.

\section{IV. 결 론}

일반적으로 $\mathrm{z}$-피닝에 의하여 얻어진 복합적층 구조물의 층간 물성의 향상은 면내 방향의 역학 적 물성의 저하보다 훨씬 큰 가치가 있다고 알려 져 있다. 예로서 준등방성 적층판의 경우에, 2 $4 \%$ 의 체적비에 해당하는 상대적으로 작은 양의 $\mathrm{z}$-핀의 함유에 의하여, 층간 강성, 충격손상에 대 한 저항성, 조인트 강도에 있어서 $50 \%$ 이상의 큰 향상을 얻을 수 있다고 하는데, 이 때 면내 강성과 강도의 저하는 약 $5 \sim 10 \%$ 정도로 상대적 으로 작다고 한다.

이러한 장점을 갖는 $\mathrm{z}$-피닝 기술에 대하여, 본 연구에서는 새로운 개념을 제시하였으며, 이 새 로운 $\mathrm{z}$-피닝 개념을 적용하여 시제품을 제작하는 
데 성공하였다. 시제작된 $\mathrm{z}$-피닝 복합적층판 시 편의 내충격 특성을 시험평가하고, 이를 일반 복 합적층판 시편과 비교하였다. 비교 결과 $\mathrm{z}$-피닝 시편들의 경우에 충격손상의 크기가 확실히 작게 나타나고 있음을 확인할 수 있었다.

저자는 본 연구를 통하여 제시된 $\mathrm{Z}$-피닝 신개 념이, 기존의 $\mathrm{z}$-피닝 기술에 비하여 상대적으로 양산에 적용하기 매우 적합한, 생산성이 뛰어난 기술인 것으로 판단하고 있다. 따라서 향후 지속 적인 연구를 통하여 새로운 $\mathrm{z}$-피닝 기술의 실용 화에 필요한 세부 요소기술들을 개발 확보할 필 요가 있는 것으로 생각한다.

\section{참고문헌}

1) Mouritz, A. P. "Review of Z-pinned Composite Laminates", Composite: Part A, Vol. 38, 2007, pp. 2383-2397.
2) Dickinson, L. C., Farley, G. L. and Hinders, M. K. "Translaminar Reinforced Composites: A Review", Journal of Composites Technology and Research, Vol. 21, Issue 1, 1999, pp. 3-15.

3) Foster-Miller, Inc, "Composite Structure Reinforcement", U.S. Patent 4808461, 1989.

4) Foster-Miller, Inc, "Method and System for Inserting Reinforcing Elements in a Composite Structure", U.S. Patent 5589015, 1996.

5) Patridge, I. K., Cartie, Denis D. R. and Bonnington, T. "Manufacture and Performance of Z-Pinned Composites", Advanced Polymeric Materials, edited G. o. Shonaike et al., CRC Press, 2003, pp. 103-138.

6) 국내외 특허출원 및 심사 진행중. 